\title{
Effect of Proposal educational program using the Keller strategy on learn some skills of gymnastics ground and the level of achievement of cognitive \\ *Dr/ Hamdy ahmed el-sayed wetwet \\ Introduction \& research problem:
}

Scientific

and

technological development have introduced many modern methods that can be used to create areas of expertise for learners so that they are prepared with a high degree of efficiency, which enables them to face the contemporary challenges. There have been numerous efforts to make teaching methods more responsive to the growing individual needs through using educational technology to modify teaching method according to student's needs, as a reaction, taking into account his needs, interests and abilities. (6: 244).

Kamal Zayton (2002) refers that Keller's plan is to develop the method of individual teaching, which appeared in the early sixties on the hands of the psychologist "Fred Keller" and his students. It has been applied broadly at the level of university faculties and is called (Personal Learning System PSI). It allows the student to move in the study of educational materials on his personal discretion, provided that he shall be familiar with course educational objectives, under the supervision of the observer who monitors learner's activity. Therefore, (monitoring) is one of new jobs that used this system and shall be added to the educational tasks such as assistance, guidance, solving problems that face the learner, contributing to creating an educational atmosphere inside the lab or classroom and evaluating the performance of the student at the end of each unit tests. This plan is interested in a part of the whole and confirm to highlight the details contained on the characterization and explanation of each line in the course. (10:96).

Fawzi El-Sherbiny and Effat El-Tantawy (2011 AD) say that the role of the teacher in Keller's Plan differs from the traditional way that is

"faculty of physical education university of El- Sadat city

Assiut Journal For Sport Science Arts 
prevailing. It is no longer the source of knowledge and the measure of learners performance, as is the case in the prevailing traditional way, but it performs some of the work and responsibilities (the most important of them are: The identification and determination of the educational material, the choice of methods and techniques of displaying the educational material, setting questions used in examinations, the determination of the extent of each learner's progress and growth in course, overcoming difficulties and obstacles faced by learners and maintaining a suitable-for-learner and positive learning environment). (9: 123).

\begin{tabular}{rrr} 
Also, & \multicolumn{2}{r}{ Mohamed } \\
Mahmoud & $(2001$ & AD)
\end{tabular} indicates that the learner receives the first unit's scientific material and studies it well according to his abilities, educational capabilities and self-speed anywhere and anytime. Then he shall test himself through self-tests. After he learns unit concepts, he shall inform his teacher and tell him that he wants to have the test of such unit. The observer conducts a test for the learner, corrects his answer and discusses it with him, especially wrong answers. The observer may ask the learner about those wrong concepts after he clarifies the question or questions related to those concepts.

If the answer in those tests is below the required level (standard of perfection), the learner shall re-study the same unit and he shall not be punished for his failure in the test. When the learner shows his perfection in the first educational unit through crossing the standard of perfection after answer sheet correction, he shall directly receive the second educational unit with its scientific material and so on to the last educational units. (15: 255 256).

The traditional methods used in the educational process made the teacher just a conveyor of information, who works on indoctrinating the learner, while the learner is a negative receiver and has no positive role or positive engagement in the learning process. Therefore, the teacher has been the main axis in the educational process and is 
considered as someone who pours information in an empty pot (the learner), making the educational process need to be reconsidered as a reaction to what happened in the last years with respect to changes in the field of education, learning environments, learners and elements of the educational process, both in terms of increasing numbers of the educated, knowledge explosion or technological innovations in the educational environment in addition to the transition imposed by the modern educational trends starting from the attention paid to the educational curriculum or the teacher to the attention paid to the learner as an individual rather than as a number between a group of learners. This is why the researcher is searching for methods that rely on self-learning and increasing learner's positivity in the learning process, while not ignoring the role of the teacher in guidance and counseling and that's what Keller's Strategy relies on. This provoked the researcher to design an educational program "educational software" using the Keller's strategy "Education Individualization" and assessing its impact on learning some of the gymnastics skills on the floor exercise device for research sample members.

\section{Research objective:}

The research aim to design an educational program "educational software" using the Keller's Strategy "Education Individualization" to assess its impact on each of the following:

1. Learning some skills on the gymnastics ground for members of research sample.

2. Academic achievement level of research sample members with respect to skills in question.

\section{Research hypotheses:}

1. There are statistically indicative differences between averages of both pre \& post measurements for the experimental group in learning the skills in question for the benefit of the average post measurement.

2. There are statistically indicative differences between averages of both pre \& post measurements for the control group in learning the skills in question for the benefit of the average post measurement.

3. There are statistically indicative differences between 
averages of both post

measurement of the the experimental group. post measurement. measurement. measurements for both experimental and control groups in learning the skills in question for the benefit of the average post measurement of

4. There are statistically indicative differences between averages of both pre \& post measurements for the experimental group in academic achievement level for the benefit of the average

5. There are statistically indicative differences between averages of both pre $\&$ post measurements for the control group in academic achievement level for the benefit of the average post

6. There are statistically indicative differences between averages of both post measurements for both experimental and control groups in academic achievement level for the benefit of the average post

experimental group.

Research procedures:

Research Methodology:

The researcher used the experimental approach using experimental design for two groups; one of them is experimental (using Keller's Strategy) and the other is control (using the traditional method). The researcher used two measurements (pre and post) for both groups because of its appropriateness for the nature of the research.

Research society \& sample:

Research

society

contained (90) purposively selected students of first year students at the Faculty of Physical Education, University of Sadat City. (30) Students were excluded to conduct surveys and thus research sample became (60) students divided into two groups, one of them is experimental (30 students) and the other is control (30 students).

Homogeneity of the research sample.

Table (1)

Description of research community and sample $(\mathbf{n}=90)$

Assiut Journal For Sport Science Arts 


\begin{tabular}{c|c|c|c|c}
\hline \hline Variables & Unit & m & st & Skweens \\
\hline \hline Length & c.m & 166.33 & 4.410 & 0.090 \\
\hline Age & Year & 18.78 & 0.628 & 1.153 \\
\hline Wight & k.g & 70.48 & 7.661 & 0.242 \\
\hline Intelligence & Grade & 61.12 & 4.44 & 0.069 \\
\hline Collection of knowledge & Grade & 7.76 & 2.401 & 0.358 \\
\hline \hline
\end{tabular}

Table (1) shows that the torsionmodulus of research a sample in the age, intelligence and some physical variables confined between $( \pm 3)$. This indicates that the homogeneity of the sample in those variables.

- Evenness of research sample members.

Table (2)

Arithmetic means,Standard deviation,(T)Value and its significanceinage,intelligence for the two groups(experimental / controlled) $\mathrm{n} 1=\mathrm{n} 2=30$

\begin{tabular}{c|c|c|c|c|c|c}
\hline \hline \multirow{2}{*}{ Variables } & \multirow{2}{*}{ Unit } & \multicolumn{2}{|c|}{$\begin{array}{c}\text { Experimental } \\
\text { group }\end{array}$} & \multicolumn{2}{c|}{$\begin{array}{c}\text { Controlled } \\
\text { group }\end{array}$} & \multirow{2}{*}{$\begin{array}{c}\text { Calculated } \\
\text { value of } \\
\text { (T) }\end{array}$} \\
\cline { 3 - 6 } & & mean & S.D & mean & S.D & $(160$ \\
\hline \hline Length & $\mathrm{Cm}$ & 161.20 & 3.847 & 163.90 & 4.811 & 2.052 \\
\hline Age & Year & 19.80 & 0.678 & 19.66 & 0.627 & 0.622 \\
\hline Wight & $\mathrm{Kg}$ & 59.40 & 6.684 & 61.50 & 9.583 & 0.905 \\
\hline Intelligence & Grade & 62.90 & 3.356 & 62.50 & 3.617 & 1.090 \\
\hline $\begin{array}{c}\text { Collection of } \\
\text { knowledge }\end{array}$ & Grade & 7.93 & 1.856 & 7.40 & 2.298 & 0.962 \\
\hline \hline
\end{tabular}

The value of"T"tabulatedatthe level $(0.05)=(2.045)$

Table (2) shows that there arestatistically insignificant differencesbetween the two groups (experimental /controlledling) in the age, intelligence and Collection of knowledge variables.This shows that there is

- Floor exercise device.

- Gymnastics mattresses. Assiut Journal For Sport Science Arts evennessbetween the two groups because the calculated value of " $T$ " is less than the tabulated value of " $T$ ".

- Means \& tools of data collection:

Devices \& tools used in the research:

- Medical scales for measuring weight. 
- Measuring tape.

- Restameter for measuring the length.

- Forms:

- Student measures registration form for the variables (age, height and weight). [Attachment No. 6].

- Skill performance evaluation form. [Attachment No. 5].

- Academic achievement test. [Attachment No. 4].

- IQ test. [Attachment No. 2].

Academic achievement test:

The researcher followed the following steps when preparing academic achievement test:

Defining the goal of the test:

This test aims to measure academic achievement level of the research sample in sports academic information related to technical aspects of skills in question for men artistic gymnastics on floor exercise device level. The researcher took into account that the objectives of this test shall be consistent with the age group.

\section{Defining test axes:}

In light of the test goal, the researcher selected an axis which is based on the technical aspect of the skills in question. This axis was identified through performing a reference survey for previous studies \&
- Computer devises.

- Video cam. research. After reviewing references specialized in gymnastics physical education, this axis was set in a form containing (70) sentences [Attachment No. 4] and was presented to experts from teaching staffs of faculties of Physical Education in order to express an opinion on the most important phrases that are commensurate with the nature of the research and its sample.

The formulation of test

\section{vocabulary:}

The researcher studied test vocabulary and their writing terms in accordance with the rules cited by scientific references and previous studies, which are commensurate with the research sample.

Determining the type of test questions:

The researcher used two types of questions to formulate academic test phrases, which are multi-choice questions (MCQs) and right \& wrong questions. The researcher took into account the availability of the following conditions in test questions: 
- Their appropriateness for the level of research sample.

- Objectivity.

- Inclusiveness.

- Measuring the objectives of program's content.

- Each word shall have only one meaning.

\section{Initial form of academic test:}

The researcher prepared the initial form of academic achievement test for skills in question. The test included, in its initial form, 70 phrases, which were presented to a group of gymnastics experts in order to be reviewed and giving guidance with amendment, deletion or addition of phrases. [Attachment No. 4]. Forms have been collected following reviewing by experts, their data was unloaded and all test phrases were accepted as a result.

\section{Test correction:}

The researcher corrected the test by giving each correct answer only one degree for

\section{Table (3)}

Indication of the differences between the top and lowest quarter in the Collection of knowledge under research

\begin{tabular}{l|c|c|c|c|c|l}
\hline \hline \multirow{2}{*}{ Variables } & \multicolumn{2}{|l|}{ Direction } & Mean of & Sum of & \multirow{2}{*}{$\begin{array}{c}\text { Z) } \\
\text { value }\end{array}$} & $\begin{array}{l}\text { Probability } \\
\text { of error }\end{array}$ \\
\cline { 2 - 6 } & Sign & Value & ranks & ranks & valn \\
\hline \hline \multirow{2}{*}{$\begin{array}{l}\text { Collection of } \\
\text { knowledge }\end{array}$} & + & 7 & 5.00 & 35.00 & & \\
\cline { 2 - 5 } & - & 7 & 10.00 & 2.50 & $2.261^{*}$ & 0.024 \\
\cline { 2 - 4 } & $=$ & 14 & & & \\
\hline \hline
\end{tabular}

Tabulated "Z" value at $(0.05)=(1.96)$ each phrase of the test phrases to have a seventy-degree test.

Determining the time required for the test:

To determine the time required for performing the academic test, the researcher used the following equation:

The time required for the test $=$ [the time taken by the first student + the time taken by another student $] / 2$

Thus, it was possible to determine the time required for the application of the academic test, which is (22 Minutes). (55: 278).

Scientific factors of academic test:

Test sincerity:

The researcher calculated differentiation sincerity through the upper spring and the lower spring on the survey sample consisting of (30) students. The following table shows the test sincerity: 
Table (3) shows statistically indicative differences between upper spring and lower spring, as the calculated value of " $\mathrm{Z}$ " is greater than its table value at significance level (0.05), which refers to test sincerity and ability to distinguish between groups.

\section{Test stability:}

To calculate the stability of the test in question, the researcher applied the method of application and re-application on a sample of 30 students from the research community and not from the original sample, with a time difference of 6 days between the first and the second application. The researcher managed to find the correlation coefficient between both applications. Table (6) illustrates the correlation coefficient between both applications.

\section{Table (4)}

The arithmetic average, standard deviation and the value of " $R$ " calculated between the first and the second applications for the Collection of knowledge under research $n=30$

\begin{tabular}{l|c|c|c|c|c|l}
\hline \multirow{2}{*}{ Variables } & \multirow{2}{*}{ Unit } & \multicolumn{2}{|c|}{$\begin{array}{c}\text { First } \\
\text { application }\end{array}$} & \multicolumn{2}{c|}{$\begin{array}{c}\text { Second } \\
\text { application }\end{array}$} & \multirow{2}{*}{$\begin{array}{c}\text { Correlation } \\
\text { coefficient }\end{array}$} \\
\cline { 3 - 6 } & & M & S.D & M & S.D & \\
\hline \hline $\begin{array}{l}\text { Collection of } \\
\text { knowledge }\end{array}$ & Grade & 10.00 & 2.803 & 9.80 & 2.757 & $0.989 *$ \\
\hline \hline
\end{tabular}

Tabulated $(\mathrm{R})$ value at the level of significance of $(0.05)=(0.377)$

Table no (4) shows thatthere isstatistically significantcorrelation at level of significance of (0.05) between the first application and the second application for cognitive testwhere the correlation coefficient between the first application and the second application reached (0.989), and it is a high correlation degree which indicatesthe test stability with a high degree.
- Proposed educational program using Keller's Strategy: [Attachment No. 1]: The researcher designed the proposed educational program using Keller's Strategy, which included an educational software containing video illustration for the skills in question \& its exercises, information of technical aspects of each of the skills in question in addition to the test questions at the end of each unit of the program. 
- The basis of the design of the program.

1. The proportional content with the objective of the program.

2. taking into account the growth characteristics of this stage.

3. The program is suitable for the capabilities that category. 4. Flexible and easy tutorial so that it can be applied in practice.

5. Provide appropriate place necessary for the implementation of the program and the possibilities. 6. take into account security and safety factors when applied to students.

7. taking into account that the program achieves the thrill and excitement for students factor.

8. take into account individual differences among students. 9. mind that fit the skills used in the program with the same search.

\section{Program objective:}

To learn some of floor exercise device skills scheduled on first year students through educational software proposed to research sample members depending on learner's self-learning in addition to guidance and counseling by the teacher.

\section{- Program content:}

The researcher designed the educational software through (AutoPlay Media Studio) program and organized software content controlled by the student through moving between software slides as follows:

The first part

\section{Introduction):}

It begins with the appearance of research title, followed by researcher name, then Instructions and Guidance to direct the student towards the way to deal with such software.

\section{(A) The main part of the educational software:}

It is controlled by the student in the section of skills in terms of speed, relay and egression depending on their level. The educational content for each skill consists of (a video for the entire skill at a normal and slow speed, a video for the technical stage with normal and slow speed, the technical aspects, educational steps \& technical stage exercises as well as a video with normal and slow speed for each exercise in addition to evaluation questions or "test your knowledge"). 
(B) Support \& feedback:

Support is performed through the display of a screen showing the result of evaluation test questions' answers for each of the skills in question. In case of correct answer, you hear clapping sound; and in case of wrong answer, you hear wrong answer alarm.

Feedback is performed through evaluation questions displayed in the software after the end of each skill required to be learned. The percentage obtained through answering the evaluation questions is calculated, upon which it will be determined to move to the practical application of the skill or to stay to re-watch the software. In the case of the practical application of the skill, and based upon skill follow-up card, it is determined to move to study another educational unit or to re-study the same unit.

\section{- The first survey:}

The first survey was conducted on Sunday, 20/09/2015 AD in order to perform scientific coefficients (sincerity and the first application) for the tests in question.

\section{- The second survey:}

The first survey was conducted on Sunday, 27/09/2015 AD in order to perform scientific coefficients (stability) for the tests in question.

\section{- Pre-measurement:}

The researcher performed premeasurements of both experimental and control groups on Sunday 10/04/2015 AD.

- The application of the program in question:

The researcher applied the proposed program according to Keller's Strategy for the experimental group and the traditional program in the period from Wednesday, 07/10/2015 AD to Wednesday 18/11/2015 AD.

- Surveys:

Table (5)

Distributionof the proposed educational program units

\begin{tabular}{c|l|l|l|l}
\hline \hline $\begin{array}{c}\text { Unit } \\
\text { time }\end{array}$ & $\begin{array}{c}\text { No. of units } \\
\text { per week }\end{array}$ & $\begin{array}{c}\text { Total units } \\
\text { per program }\end{array}$ & $\begin{array}{c}\text { No. of weeks } \\
\text { of the } \\
\text { program }\end{array}$ & $\begin{array}{c}\text { No. of } \\
\text { months of the } \\
\text { program }\end{array}$ \\
\hline \hline $90 \mathrm{~min}$ & 2 units & 14 units & 7 weeks & $\begin{array}{l}\text { a month and } \\
\text { three weeks }\end{array}$ \\
\hline \hline
\end{tabular}

Assiut Journal For Sport Science Arts 
Post-measurement:

Post-measurement was performed on Saturday, 21/11/2015 AD for the academic test, and on Sunday, 22/11/2015 AD for the skills in question.

Statistical processes used in the research:
Average, standard deviation, torsion modulus, Berson correlation coefficient, nonparametric counting, "ttest" variation ration equation (improvement).

Results display \& discussion: Results of the first hypothesis:

Table (6)

Significance of differences between both pre and post-measures for the experimental group with respect to the skills in question

\begin{tabular}{|c|c|c|c|c|c|c|c|}
\hline \multirow{2}{*}{ variables } & \multicolumn{2}{|c|}{ pre } & \multicolumn{2}{|c|}{ post } & \multirow{2}{*}{$\begin{array}{c}\text { Different } \\
\text { between } \\
\text { means }\end{array}$} & \multirow[b]{2}{*}{ percentage } & \multirow{2}{*}{$\begin{array}{c}\mathbf{T}^{\prime \prime} \\
\text { value" }^{\prime \prime}\end{array}$} \\
\hline & mean & st & mean & st & & & \\
\hline Front roll & 1.27 & 0.450 & 6.80 & 0.847 & $31.142 *$ & $81.32 \%$ & $31.142 *$ \\
\hline Head stand & 1.33 & 0.479 & 7.20 & 0.664 & $33.018^{*}$ & $81.53 \%$ & $33.018^{*}$ \\
\hline cartwheel & 1.50 & 0.509 & 6.87 & 0.819 & $30.483 *$ & $78.17 \%$ & $30.483^{*}$ \\
\hline Hand stand & 1.00 & 0.643 & 6.78 & 1.106 & $31.878^{*}$ & $84.13 \%$ & $31.878^{*}$ \\
\hline $\begin{array}{l}\text { Front } \\
\text { balance }\end{array}$ & 0.43 & 0.626 & 6.80 & 1.279 & $22.462 *$ & $93.68 \%$ & $22.462 *$ \\
\hline $\begin{array}{l}\text { Front roll } \\
\text { open }\end{array}$ & 0.17 & 0.461 & 6.63 & 0.669 & $37.797 *$ & $97.44 \%$ & $37.797 *$ \\
\hline Back roll & 0.20 & 0.407 & 7.07 & 1.081 & $38.646^{*}$ & $97.17 \%$ & $38.646^{*}$ \\
\hline
\end{tabular}

Value of " $t$ " in $(0.05)=(1.699)$

Table (6) shows statistically indicative differences between averages of pre and post-measures for the experimental group in learning the skills in question for the benefit of average postmeasure as the calculated value of " $\mathrm{T}$ " is greater than its table value at significance level (0.05).
- Discussing the results of the first hypothesis:

Table (6) shows statistically indicative differences between averages of pre and post-measures for the experimental group in skill variables in question for the benefit of average postmeasure as the calculated value of " $\mathrm{T}$ " is greater than its table 
value at significance level (0.05).

According to the researcher, these differences are due to the educational program using Keller's Strategy through an educational software, which provided the learner with a new access to gain information individually in a proper sequence with the restoration and recovery of such information in a manner suitable to his personal abilities. Also, the presentation of educational material within the program and displayed gradually and simply in different ways such as photos and video at normal and slow speed made the learner has the desire to perform like the form he watched then correct his performance errors by referring once again to the program in case of non-performance of skill as required.

The creation of a new learning environment for the learner, through the involvement of all of his senses, stimulating the motivation towards learning, helping him with organized scientific thinking through educational software and making him proceed in the educational process according to his desire, speed, abilities, his sense of self-learning and his role in the educational process, led to learn and understand how to perform gymnastics skills on the floor exercise device in question in a good manner.

Keller's Strategy is an educational system which is described as an educational development technology. He put Reinforcing Theory in its scientific framework to become a framework for a full course, where learners work according to their own speed so that each learner has to show his perfection in each unit before being allowed to move to the next one, taking into account individual differences and allowing each learner be proceed according to his own speed making the use of educational software along with Keller's Strategy to individualize education more effective \& positive in the educational process and more considerate of the difference and exclusivity of learners, especially in the light of changes hitting the educational process, as well as ensuring its consistency with modern 
technology. (2: 363, 362) (17: 141).

This result agrees with studies of Sally Mohamed Abdel-Latif (2010 AD) (5), Nevin Hanafy Abdel-Khaliq (2005 AD) (19), Hamid Mohammed El-Komy (2007 AD) (3), Hesham Mohamed Anwar (2008 AD) (12), Mohammad Abdo Khedr (2010 AD) (13), Mai Talaat Afifi (2010 AD) (18), Reyad Abed Ali (2004 AD) (7), Mohamed Abdel-Majid

Abou-Doya
(2016 AD) (14) and Stein Gulian (1996 AD) (21).

Thus

the

first

hypothesis is achieved, which states "There are statistically indicative differences between averages of both pre \& post measurements for the experimental group in learning the skills in question for the benefit of the average post measurement".

- Results of the second hypothesis:

\section{Table (7)}

Significance of differences between averages of both pre \& postmeasurements for the control group for the skills in question

\begin{tabular}{l|l|l|l|l|l|l|l}
\hline \hline \multirow{2}{*}{ variables } & pre & \multicolumn{3}{|l|}{ post } & $\begin{array}{l}\text { Different } \\
\text { between } \\
\text { means }\end{array}$ & percentage & $\begin{array}{l}\text { T" } \\
\text { value" }\end{array}$ \\
\cline { 2 - 8 } & mean & st & mean & st & & \\
\hline \hline Front roll & 1.17 & 0.531 & 5.03 & 0.850 & 3.86 & $76.74 \%$ & $36.500^{*}$ \\
\hline Head stand & 1.00 & 0.587 & 5.13 & 0.776 & 4.13 & $80.51 \%$ & $29.651^{*}$ \\
\hline cartwheel & 1.13 & 0.571 & 5.23 & 0.971 & 4.1 & $78.39 \%$ & $20.530^{*}$ \\
\hline Hand stand & 0.77 & 0.504 & 5.07 & 0.640 & 4.3 & $84.81 \%$ & $25.729^{*}$ \\
\hline $\begin{array}{l}\text { Front } \\
\text { balance }\end{array}$ & 0.40 & 0.498 & 4.97 & 0.765 & 4.57 & $91.95 \%$ & $25.748^{*}$ \\
\hline $\begin{array}{l}\text { Front roll } \\
\text { open }\end{array}$ & 0.13 & 0.346 & 4.90 & 0.845 & 4.77 & $97.34 \%$ & $30.416^{*}$ \\
\hline Back roll & 0.30 & 0.466 & 4.83 & 0.699 & 4.53 & $93.79 \%$ & $30.306^{*}$ \\
\hline \hline
\end{tabular}

Value of " $t$ " in $(0.05)=(1.699)$

Table (7) shows statistically indicative differences between averages of pre and post-measures for the control group in learning the skills in question for the

benefit of average postmeasure as the calculated value of " $\mathrm{T}$ " is greater than its table value at significance level (0.05).

Assiut Journal For Sport Science Arts 
Discussing the results of the second hypothesis:

$$
\text { Table (7) shows }
$$

statistically indicative differences between averages of pre and post-measures for the control group in learning the skills in question for the benefit of average postmeasure as the calculated value of " $\mathrm{T}$ " is greater than its table value at significance level (0.05). According to the researcher, these differences are due to the traditional method, which is based in essence on the verbal explanation and model performance by the teacher, where the role of the learner is limited to receiving information and trying to perform the skills learned in the best possible way.

The traditional method used does not deserve all this attack by discharging it as it provides a direct contact between the teacher and the learner. It has shown a positive progress when comparing premeasure degrees to postmeasure ones. This method is based on the teacher as a major axis in the educational process through the verbal introduction of skill, module display and the gradual presentation for the skill along with providing feedback and continuous assessment during skill learning, in addition to that the student gets used to work in this manner in most of other subjects. All this contributed to the formation of much of the scientific knowledge of the skills in question and improving skill performance level for the control group students.

This result agrees with studies of Sally Mohamed Abdel-Latif (2010 AD) (5), Nevin Hanafy Abdel-Khaliq (2005 AD) (19), Hamid Mohammed El-Komy (2007 AD) (3), Hesham Mohamed Anwar (2008 AD) (12), Mohammad Abdo Khedr (2010 AD) (13), Mai Talaat Afifi (2010 AD) (18), Reyad Abed Ali (2004 AD) (7) and Mohamed Abdel-Majid AbouDoya (2016 AD) (14).

Thus the second hypothesis is achieved, which states "There are statistically indicative differences between averages of both pre \& post measurements for the control group in earning the skills in question for the benefit of the average post measurement". Results of the third hypothesis: 
Table (8)

Significance of differences between averages of both post measures for the experimental and control group for the skills in question $\mathbf{n}=\mathbf{3 0}$

\begin{tabular}{|c|c|c|c|c|c|c|c|}
\hline \multirow{2}{*}{ variables } & \multicolumn{2}{|c|}{ experimental } & \multirow[b]{2}{*}{ mean } & \multirow[b]{2}{*}{ st } & \multirow{2}{*}{$\begin{array}{c}\text { Different } \\
\text { between } \\
\text { means }\end{array}$} & \multirow{2}{*}{ percentage } & \multirow{2}{*}{$\begin{array}{c}\text { T" } \\
\text { value" }\end{array}$} \\
\hline & mean & st & & & & & \\
\hline Front roll & 6.80 & 0.847 & 5.03 & 0.850 & 1.77 & $35.19 \%$ & $6.880 *$ \\
\hline $\begin{array}{l}\text { Head } \\
\text { stand }\end{array}$ & 7.20 & 0.664 & 5.13 & 0.776 & 2.07 & $40.35 \%$ & $10.475^{*}$ \\
\hline cartwheel & 6.87 & 0.819 & 5.23 & 0.971 & 1.64 & $31.36 \%$ & $5.977 *$ \\
\hline $\begin{array}{l}\text { Hand } \\
\text { stand }\end{array}$ & 6.78 & 1.106 & 5.07 & 0.640 & 1.71 & $33.73 \%$ & $6.924 *$ \\
\hline $\begin{array}{l}\text { Front } \\
\text { balance }\end{array}$ & 6.80 & 1.279 & 4.97 & 0.765 & 1.83 & $36.82 \%$ & $7.781 *$ \\
\hline $\begin{array}{l}\text { Front roll } \\
\text { open }\end{array}$ & 6.63 & 0.669 & 4.90 & 0.845 & 1.73 & $35.31 \%$ & $7.390 *$ \\
\hline Back roll & 7.07 & 1.081 & 4.83 & 0.699 & 2.24 & $46.38 \%$ & $8.275^{*}$ \\
\hline
\end{tabular}

value of " $\mathrm{t}$ " in $(0.05)=(1.699)$

Table (8) shows statistically indicative differences between averages of both post measures for the control and experimental group in learning the skills in question for the benefit of average post-measure of the experimental group as the calculated value of " $\mathrm{T}$ " is greater than its table value at significance level (0.05).

Discussing the results of the third hypothesis:

Table (8) shows statistically indicative differences between averages of both post measures for the control and experimental group in learning the skills in question for the benefit of average postmeasure of the experimental group as the calculated value of "T" is greater than its table value at significance level (0.05).

The researcher attributed these differences to the use of Keller's Strategy through an educational software that took into account individual differences among learners, comparing between learner's level and his own abilities and working on developing theses abilities so that he doesn't get Assiut Journal For Sport Science Arts 
frustrated when he works with the rest of his colleagues who have different levels of performance.

The researcher also used an educational software featured by the presence of photos and videos at normal \& slow speeds and containing the information of each skill so that it can be repeated more than once. This helped to learn the skills in question.

The use of Keller's strategy "Education Individualization" doesn't allowed the student to move from one level to another and from one unit to another until he reaches the required level of perfection which allow him a chance to succeed and achieve positive results.

This is confirmed by "Karam Louise Shehata" (1994 AD) (11) and "Mervat Samir" (2002 AD) (16), where they assured that the individual learning helps to achieve positive results for the learning process for all students at all levels.

In this regard, "Zaher Ahmed" (1996 AD) states that the individual learning system does not allow performance level in any skill to be less than perfection level, and that the failure of the learner to reach the degree of perfection means that he needs to re-learn so that his level reaches to the point of perfection. This is what Keller's Strategy achieves. (8: 246)

Najarlawrance (2005

AD) adds that the degree of learner's admiration with nontraditional learning methods works to attract his attention towards the subject of learning, which increases his dynamic and academic achievement. This is also what Keller's strategy achieves. (20: 134).

Kamal Zayton (2004 AD) refers that the old view of education (the traditional way) see the learner as just a mind where information is poured. $\mathrm{He}$ is just a receiver as of the modern view of learning (selflearning) (individual learning), where he is seen a reactant living organism, aiming of his growth and maturity. So, the target here is not to save information, but to build the learner's knowledge according to his own processing for such information. (10:34).

Thus the third hypothesis is achieved, which states "There are statistically indicative differences between averages of both post 


\begin{tabular}{|c|c|}
\hline $\begin{array}{lll}\text { measurements } & \text { for } & \text { both } \\
\text { experimental and } & \text { control }\end{array}$ & $\begin{array}{l}\text { average post measurement of } \\
\text { the experimental group". }\end{array}$ \\
\hline $\begin{array}{l}\text { groups in learning the skills in } \\
\text { question for the benefit of the }\end{array}$ & $\begin{array}{l}\text { - Results of the forth } \\
\text { hypothesis: }\end{array}$ \\
\hline
\end{tabular}

Table (9)

Significance of differences between both pre and post measures of the experimental group for academic achievement in question $n=30$

\begin{tabular}{|c|c|c|c|c|c|c|c|}
\hline \multirow[b]{2}{*}{ variables } & \multicolumn{2}{|l|}{ pre } & \multicolumn{2}{|l|}{ post } & \multirow{2}{*}{$\begin{array}{l}\text { Different } \\
\text { between } \\
\text { mean }\end{array}$} & \multirow[b]{2}{*}{ percentage } & \multirow{2}{*}{$\begin{array}{l}\text { "T" } \\
\text { VALU }\end{array}$} \\
\hline & mean & st & mean & st & & & \\
\hline $\begin{array}{l}\begin{array}{l}\text { Collection of } \\
\text { knowledge }\end{array} \\
\end{array}$ & 6.24 & 1.974 & 61.59 & 5.374 & 55.35 & $89.87 \%$ & $76.471^{*}$ \\
\hline
\end{tabular}

Value of " $t$ " in $(0.05)=(1.671)$

Table (9) shows difference between the two statistically indicative averages reached (55.35).

differences between averages of both pre \& post measurements for the experimental group in academic achievement level for the benefit of the average post measurement as the calculated value of "T" is greater than its table value at significance level (0.05).

- Discussing the results of the third hypothesis:

Table (9) shows statistically indicative differences between averages of both pre \& post measurements for the experimental group in academic achievement level for the benefit of the average post measurement as the calculated value of " $\mathrm{T}$ " is greater than its table value at significance level (0.05). The The proposed program using Keller's Strategy (Education Individualization) through an educational software helped to divide the educational situation, led to the increase of opportunities for success and reduced erroneous responses, leading to avoid learner's negativity and increase his positive participation in the acquisition of knowledge and therefore the survival of learning impact.

This is what appeared in the results of the previous table, where students got high scores after using Keller's Strategy. The researcher took into account that the educational software shall include all information of technical aspects of each skill, Assiut Journal For Sport Science Arts 
in addition to providing an opportunity and sufficient time for the learner to re-read the information of the technical aspects of each skill more than once, which helped to fix such information in minds of research sample students.

Table (10)

The containment of the end of each unit of the program on a set of questions provided students with experience on the presentation of questions and how to answer them.

- Results of the fifth hypothesis:

Significance of differences between both pre and post measures of the control group for academic achievement in question $\mathbf{n}=\mathbf{3 0}$

\begin{tabular}{|c|c|c|c|c|c|c|c|}
\hline \multirow[b]{2}{*}{ variables } & \multicolumn{2}{|c|}{ pre } & \multicolumn{2}{|c|}{ post } & \multirow{2}{*}{$\begin{array}{c}\text { Different } \\
\text { between } \\
\text { mean }\end{array}$} & \multirow[b]{2}{*}{ percentage } & \multirow{2}{*}{$\begin{array}{c}\text { "T"' } \\
\text { VALU }\end{array}$} \\
\hline & mean & st & mean & st & & & \\
\hline $\begin{array}{l}\text { Collection of } \\
\text { knowledge }\end{array}$ & 5.81 & 2.045 & 40.86 & 7.951 & 35.05 & $85.78 \%$ & $36.253 *$ \\
\hline
\end{tabular}

Value of " $t$ " in $(0.05)=(1.671)$

Table (10) shows statistically indicative differences between averages of both pre \& post measurements for the control group in academic achievement level for the benefit of the average post measurement as the calculated value of " $\mathrm{T}$ " is greater than its table value at significance level (0.05).

- Discussing the results of the third hypothesis:

Table (10) shows statistically indicative differences between averages of both pre \& post measurements for the control group in academic achievement level for the benefit of the average post measurement as the calculated value of " $\mathrm{T}$ " is greater than its table value at significance level (0.05). The difference between the two averages reached (35.05).

The reason for this progress of the control group in academic achievement level is due to the feasibility of the traditional way that can not be overlooked, and which relies on learners' receiving of information and concepts from the teacher. Where the teacher explains the skill, displays its model and gradually provides feedback during each stage of education. In addition, the traditional way highlights

Assiut Journal For Sport Science Arts 
social relations and humanitarian aspects between them, and increases learners' motivation to learn.

This result is consistent with the results of "Reyad Abed Ali" (2004 AD), "Nevin Hanafy Abdel-Khaliq" (2005 AD), "Hamed Mohammed ElKomy" (2007 AD) and "Hesham Mohamed Anwar" (2008 AD).

\section{Table (11)}

hypothesis is achieved, which states "There are statistically indicative differences between averages of both pre \& post measurements for the control group in academic achievement level for the benefit of the average post measurement".

Results of the sixth hypothesis:

Significance of differences between both post measures of the experimental and the control group for academic achievement in question $\mathbf{n}=\mathbf{6 0}$

\begin{tabular}{l|l|l|l|l|l|l|l}
\hline \hline \multirow{2}{*}{ Variables } & \multicolumn{2}{|l|}{ Expremental } & \multicolumn{2}{|c|}{ Control } & $\begin{array}{l}\text { Different } \\
\text { between } \\
\text { mean }\end{array}$ & percentage & "T" \\
& mean & st & mean & st & \\
\hline $\begin{array}{l}\text { Collection of } \\
\text { knowledge }\end{array}$ & 61.59 & 5.374 & 40.86 & 7.951 & $21.959^{*}$ & $50.73 \%$ & \\
\hline \hline
\end{tabular}

Value of " $t$ "' in $(0.05)=(1.671)$

Discussing the results of the sixth hypothesis: according to the researcher, this is due to the fact that the proposed program using keller's strategy of education individualization through an educational software was more positive and effective in academic achievement than the traditional method (used), because the proposed program takes into account individual differences among various levels and allows students to enter the exam more than once regardless of previous failure attempts. this would increase the likelihood of success and the level of knowledge, information and facts collection, and the ease to remember, understand and restore educational subject in an easy way. also, the use of educational software and its diversity helped to raise learner's attention, stimulate him for further learning and to 
provide a variety of experiences suitable for levels of students and their abilities.

it is emphasized that both individual education and multimedia have effectiveness and positive impact on the academic achievement, especially that linking cognitive aspects to multimedia used led to the improvement of the experimental group.

this is in line with what "mohammed abdel-majid" (2016 ad) referred to, where he said that the educational software using keller's strategy provides learners with new accesses to acquire information individually with an appropriate gradation and the retrieval of information according to their personal abilities. also, the introduction of educational material within the software and its display gradually and simply through images of basic skills and slow $\&$ normal speed animation video for performance made the learner want to become close to this image along with linking the same to the practical performance he watched before, then imagining it and correcting performance errors by enabling him to return to the program again to get an immediate support when not being able to perform the skill or any part of it. this leads to the improvement and development of technical performance and increases academic achievement for skills in question.

"al-ghareib ismail" (2009 ad) and "hussein abdel-basset" $(2011 \mathrm{ad})$ refer that the use of educational software prepared using keller's strategy is working to simulate real-life, provide constant-direction communication environment linking between classroom and learner's environment, make educational process more interactive and addresses more than one sense of the learner. this leads to attracting his attention and stimulating his learning tasks. it increases the individual interaction, reduces the dread of experimentation and develop curiosity, innovation and teamwork. (1: 63) (4: 87).

\section{conclusions:}

1- the educational program using keller's strategy through an educational software has a positive impact on learning gymnastics skills in question on floor exercise device. 
2- the educational program using keller's strategy through an educational software has a positive impact on research sample members in academic achievement with respect to skills in question.

3- there are statistically indicative differences between averages of both pre \& post measurements for the experimental group in learning the skills in question for the benefit of the average post measurement.

4- there are statistically indicative differences between averages of both pre \& post measurements for the control group in learning the skills in question for the benefit of the average post measurement.

5- there are statistically indicative differences between averages of both post measurements for both experimental and control groups in learning the skills in question for the benefit of the average post measurement of the experimental group.

6- there are statistically indicative differences between averages of both pre \& post measurements for the experimental group in academic achievement level for the benefit of the average post measurement.

7- there are statistically indicative differences between averages of both pre \& post measurements for the control group in academic achievement level for the benefit of the average post measurement.

8- there are statistically indicative differences between averages of both post measurements for both experimental and control groups in academic achievement level for the benefit of the average post measurement of the experimental group.

\section{recommendations:}

1. the application of the educational software, prepared using keller's strategy, to learn skills of gymnastics on the floor exercise device for students of physical education.

2. the application of the educational software, prepared using keller's strategy, to learn skills of gymnastics on other devices.

3. paying attention to using modern methods and techniques in teaching different skills, especially in gymnastics. 4. paying attention to academic content of learners 
during teaching various gymnastics skills.

\section{References}

1. al- ghareib ismail (2009ad), electronic education: from application to proficiency \& quality, version (1), book world for publication \& distribution, cairo.

2. tawfiq ahmed marie, mohammed mohammed alhela (1998 ad), education individualization, dar el-fikr for printing, publication \& distribution.

3. hamed mohammed alkomy (2007 ad), the impact of keller's strategy for education individualization using hypermedia on shooting performance level \& academic achievement in handball, sports sciences \& arts journal, volume 28, faculty of physical education for girls, helwan university.

4. hussein mohammed abdel-basseit (2011 ad), digital educational units \& modern educational technology, book world for publication \& distribution, cairo.

5. sally mohammed abdel-latif (2005 ad), the effectiveness of a proposed educational program using keller's strategy (education individualization) through multimedia on learning many hockey skills by femalestudents of faculty of physical education, tanta university, ph.d. thesis, faculty of physical education, tanta university.

6. ghadnana saied almoqbel (1990 ad), the impact of using keller's method on teacher female-students' academic achievement in geography, and its relation to personality styles \& selflearning trend, unpublished ph. d. thesis, faculty of girls, ainshams university.

\section{7. reyad aded ali hussein} (2014 ad), the impact of using keller's strategy \& holograms on learning many attacking skills of fencing, scientific production, volume 12 , version 2 , magazine of the faculty of physical education for girls, helwan university.

8. zaher ahmed (1996 ad), the impact of using may visual methods on some jumps performance level in modern technical exercises, unpublished master thesis, faculty of physical education for girls, helwan university, cairo.

9. fawzy el-sherbiny, effat el-tantawy (2011 ad), self- 
learning using educational modules, book world, cairo.

10. kamal abdel-hameed zayton (2002 ad), modules \& skills of teaching, book world, cairo, version 2 .

11. kareem louise shehata (1994 ad), effectiveness of using keller's strategy of education individualization in teaching many basic sports skills for the $1^{\text {st }}$ year students of the basic education, faculty of physical education, asyut university.

12. kamal abdel-hamed zayton (2004 ad), education technology in the time of information \& communication, book world, cairo.

13. hesham mohammed anwar (2008 ad), the impact of an educational program using keller's strategy (education individualization) on performance level of shooting while falling in handball, sports sciences \& arts journal, volume 29 , version 1 , faculty of physical education for girls, helwan university.

14. mohammed abdo mohammed khedr (2010 ad), the effectiveness of an educational program using keller's strategy in learning long jump skill for preparatory stage students, master thesis, faculty of physical education for boys, zagazig university.

15. mohammed abdelmajid abou-donya (2016 ad), the impact of keller's strategy \& peer guidance on learning some of athletics skills, unpublished ph. d. thesis, faculty of physical education, sadat city university.

16. mohammed mahmoud al-hela (2001 ad), teaching methods \& strategies, dar almasera for publication \& distribution, version 2 , oman.

17. mevat ali hassan khafagah, hesham mohammed sobhy hassanein (2000ad), evaluation of educational techniques usage in teaching courses of faculties of physical education in egypt, a published research in the $1^{\text {st }}$ annual scientific conference (quality education strategy in egypt), quality education, damietta, mansoura university.

18. mervat hassan samir $(2002 \mathrm{ad})$, the usage of many educational techniques in learning many gymnastics skills, and its effect on achieving proficient skill performance level, published research, volume 2, scientific conference for sports, arab community development and $21^{\text {st }}$ century requirements, 
faculty of physical education for girls, helwan university, cairo.

19. mai tallat tolbah afify $(2010 \mathrm{ad})$, the impact of an educational software using keller's strategy of education individualization on learning results of basketball, scientific production, magazine of faculty $\mathrm{f}$ physical education for girls, helwan university.

20. nevin hanafy abdel khaliq (2005 ad), the impact of a proposed educational program using keller's strategy of education individualization through multimedia on learning many ballet skills by female-students of faculty of physical education, tanta university, faculty of physical education, tanta university.

\section{1. najar}

lawrence(2005)"multimedia information and learning "journal of educational multimedia and hypermedia.

\section{2. - stein julian, u(1996)}

practical new technologies in physical education at gear mason university, v,s virginia spo,.

23. ;http://search.mandumah .com/search/results?lookfor $=\%$ d9\%83\%d9\%8a\%d9\%84\%d8 $\%$ b1\&type $=$ allfields $\&$ submit $=$ $\% \mathrm{~d} 8 \%$ a7\%d8\%a8\%d8\%ad\%d8 $\% \mathrm{ab}$ 